13 A Mad Couple Well Match'd, Steen H. Spove (ed.), (New York, London: Garland, 1979). Another example is Victoria's performance as a courtesan in The Novella'Give me my Lute; and set me for the signe / Of what I meane to be, the fam'd Novella' (1653 Five New Playes, sig. K1r). I would like to thank Lucy Munro for this suggestion.

14 Catherine Richardson considers the personal, economic and cultural significances of stage properties in 'Properties of domestic life: the table in Heywood's $A$ Woman Killed with Kindness', in Jonathan Gil Harris and Natasha Korda (eds), Staged Properties in Early Modern English Drama (Cambridge, 2002), 129-52. Although specifically concerned with household props in domestic tragedy, Richardson's exploration of the sorts of connections which could be made between the audience's imagination and the properties brought onto the stage raises useful and interesting issues when considering Brome's imaginative placement of a building (as large stage property) onto the fabric of the theatre.

\title{
Richard Brome's Contract and the Relationship of Dramatist to Company in the early modern period
}

In 1635, Richard Brome made a career decision that was to have significant consequences for the understanding of early-modern theatre history. $\mathrm{He}$ agreed to the contract drafted on the 20 July made with the King's Revels company, then under the leadership of Richard Gunnell, which bound his services as a playwright exclusively to the Salisbury Court theatre. Brome's contract has been interpreted as symptomatic of changing modes of theatrical production and regulation into the Caroline period, and as exemplary of the condition of the 1630s dramatist, bound under contractual agreement to impresarial management. ${ }^{1}$ Andrew Gurr describes the impresario system, as exemplified by Philip Henslowe, Christopher Beeston, and Gunnell (and, later, Richard Heton) as 'an autocratic form of rule imposed on a profession which had grown into being by means of a long tradition of collaborative and democratic practices'. ${ }^{2}$ This kind of management is placed in opposition to the 'collective responsibility' of the King's Men, ${ }^{3}$ and has contributed to the perception of the decline of drama and its quality into the 1630s, in which theatrical managers become 'entrepreneurs rather than players, individualists in commerce, not stars in the teamwork of performance', ruthlessly binding playwrights to their whims. ${ }^{4}$ 
This model has become an accepted fact of Caroline drama. The interpretation of Brome's contract has become fundamental to the way in which we consider these dramatists and the autonomy that they had within the professional theatrical market. The distinctions between whether a dramatist sold a play to a company, was commissioned by that company or contractually bound to it are crucial to the personal and professional relations that we construct, and the characters and motivations of the history that we tell: they affect the whole landscape of early modern stage history. How far Brome's contract is treated as representative of routine theatre practice impacts not only upon the ways in which individual dramatists are thought to have worked and negotiated within the theatrical marketplace, but also those in which managers and companies operated, and the means by which they accumulated competitive repertories. This paper aims to reassess the nature and implications of Brome's contract, in the context of the history of theatrical contracts and the production rates and patterns of his contemporaries. It takes issue with G. E. Bentley's statement that 'the primary significance' of the Brome contract documents lies within 'their revelation of actual customary relations between a playwright and an acting company', and attempts to show that the current model for understanding the commitments and obligations of the early modern playwright requires careful reassessment. ${ }^{5}$

To the best of our knowledge, Brome's contract itself no longer survives. We know of it only because Brome violated its terms, prompting a Requests Proceedings Bill of Complaint filed on 12 February 1640 by the company then renting the Salisbury Court, Queen Henrietta's Men. In these documents, Richard Heton-Gunnell's successor as manager of the theatre-and the actors, claimed that Brome had agreed 'for the terme of three years ... with his best Art and Industrye [to] write everye yeare three plays and deliver them to the company of players there acting for the time being'. ${ }^{6}$ Furthermore, they added that Brome had assented that he would not provide 'any play or any part of a play to any other players or play house'. In return, Brome would receive a regular payment of fifteen shillings a week, and an extra day's profit for every new play. By 1638 however, Brome had failed to deliver four of his nine promised plays. He had also sold 'one of the playes which he made ... in the said time unto Christopher Beeston gent and William Beeston' at the Cockpit. ${ }^{7}$ Despite this breach, Heton renewed the contract in 1638. The revised contract specified that Brome's salary would rise to twenty shillings a week, but demanded the same production rate of three plays annually, for an extended term of seven years. In addition, Brome was required to produce 
the plays owed to the company from the prior agreement. Once more, Brome failed to do so. By the end of the year, he was in arrears by one new play. The Heton complaint records that by this time, Brome had 'wholly applie[d] himself unto the said Beeston and the Companie of players Acting at the playhouse of the Phoenix [or Cockpit] in Drury Lane'. ${ }^{8}$ As a further complication, Brome argued in his answer to the Requests that he had composed a new play for Heton around September of 1639, and another before Easter, but that both had been refused by the company.

The story told by the court proceedings reveals a narrative of tension and antagonism. Yet the cause of this disruption to professional dealings-the contract itself-is figured in criticism as an essential component of company management, regulating and assuring consistent dramatic output. ${ }^{9}$ An overview of contractual precedents will provide some framework against which to situate the nature of the Brome contract, and determine the validity of its application to the practices of other playwrights. There exists only one other known formal contract to bind a playwright in similar manner to an employer, made between Lawrence and John Dutton, Thomas Goffe, and Rowland Broughton. ${ }^{10}$ Again, this contract is documented only as a consequence of its dishonouring - a lawsuit of 26 January 1572/3 records that Broughton failed (perhaps unsurprisingly) to deliver the eighteen plays that he had promised at periodic deadlines throughout the space of one year. Such measured demands, although an extreme case, had proved an unsuccessful mode of theatrical production sixty years prior to Brome's agreement.

Roslyn Knutson has also drawn attention to two contracts documented in Henslowe's papers. The first, made on 28 February 1598, is an agreement between Henslowe (on behalf of the Admiral's Men) and Henry Porter. Henslowe had lent Porter forty shillings 'in earnest of' a play, but had agreed with Porter that 'for the Resayte of the money he gave me his faythfulle promysse that I shold have alle the boockes $\mathrm{w}^{\text {ch }}$ he writte him sellfe or $\mathrm{w}^{\text {th }}$ any other'. ${ }^{11}$ This agreement establishes Henslowe's rights to exclusive ownership of all of Porter's plays-even those produced collaboratively-but does not specify an expected rate of production, which-according to our understanding of the later 1630s company management - is a crucial component of Brome's undertaking. Furthermore, this 'contract' appears to be situated within a faceto-face (or oral) era of theatrical production: a 'faythfull promysse' is all that is required, and the lack of formalisation suggests that this kind of assurance was sufficient both for the manager and the playwright. There is one further entry in Henslowe's papers that might suggest the contractual commitment 
of Henry Chettle to Henslowe. On 25 March 1602, Henslowe lent Thomas Downton and Edward Alleyn three pounds to secure Henry Chettle's services 'to writte for them the some of' an unspecified number of plays. ${ }^{12}$ The entry appears to be unfinished, and fails to specify the terms of the arrangement. This ambiguity aside, the arrangement with Chettle resembles more of a standard play commission, common to the way that Henslowe solicited plays for the Admiral's Men during this time, than the kind of contractual terms that Brome was subject to. This evidence suggests that although dramatists often made agreements with managers concerning the destination and ownership of the plays that they produced, formalized contracts in the sense that are suggested by the Brome court depositions were deemed neither necessary implementation nor standard theatrical practice.

Contracts between players and their managers were far more common. After Richard Jones, Thomas Downton, Robert Shaw, and William Bird left the Admiral's Men in 1597 to play for Pembroke's Men at Langley's Swan, the ensuing scandal over The Isle of Dogs necessitated their prompt return to Henslowe at the Rose, who consequently enforced bonds from all company members. ${ }^{13}$ Langley had similarly imposed bonds and sureties upon five of Pembroke's Men at their opening, of $100 l$ per actor ensuring their employment for twelve months. ${ }^{14}$ These bonds appear to have set a formulaic precedent for future company procedure, as Gunnell also arranged a contractual agreement with his players in 1624 who obliged 'themselves to the said $\mathrm{Mr}$ Gunnell to stay and play there' at his theatre. ${ }^{15}$

The economic exigencies of owning permanent playhouses, as theatre historians now recognize, resulted in the requirement of managers such as Henslowe and Gunnell to formalize relations between players in order to regulate income. As K.E. McLuskie and Rebecca Rogers observe, 'fixed London venues increased the stakes: theatrical activity became a bigger, more commercial enterprise, and in turn became a more capital-driven, contractgoverned venture. ${ }^{16}$ It is important to note the conditions under which contractual bindings arose, however. In the cases of Henslowe, who had recently experienced the autonomous caprice of his players, and Langley, at the outset of a new theatrical investment, these were times of stress. Gunnell enforced his bonds to the Palsgrave's Men during perpetual financial struggle following the burning of the Fortune playhouse. Knutson has suggested of the Henslowe/Porter arrangement that it may have anticipated the imminent move of the Chamberlain's Men to the nearby Maid Lane. ${ }^{17}$ The evidence suggests that contracts constituted insurance policies during periods of disruption and 
uncertainty, and are not to be classified as generally representative. Furthermore, while systems of bonds and contracts amongst players continued to hold currency over the decades, Henslowe's 1597 bonds suggest that it was neither a customary nor an appropriate means of managing relations with playwrights: Thomas Heywood was contracted to the company in the specific capacity of a player, agreeing 'not to playe any where public about London' besides the Rose, and while Jonson returned from prison to Henslowe and wrote five plays for the company in five years, there survives no evidence of a formal agreement. E. K. Chambers has suggested that Jonson may have invested in a share, in a voluntary expression of allegiance to the company, but evidence is lacking, and Jonson does not appear to have followed the economic logic of shareholding as his concurrent commitment to the Queen's Revels and Chamberlain's Men reveals. ${ }^{18}$

The notion that playwrights felt themselves free to form their own allegiances and locate buyers for plays, despite 'cementing' relations with managers in the form of either a promise or pre-payment, is also evidenced by Robert Daborne's behaviour while working for Henslowe. Henslowe had commissioned The Arraignment of London from him, but Daborne's suggestions that he might sell it on to the King's Men suggests that the cement that held dramatists to companies was nothing like as strong as Brome's contract might imply. ${ }^{19}$ The apparent negotiability of commitments prior to the emergence of the 1640 court depositions might explain the notable discrepancies between the expectations of the Salisbury Court management and Brome himself, who claimed that he had harboured misgivings about the stringent requirements that Gunnell's contract made of him, and had been 'unwilling to undertake ... more than he could well perform'. ${ }^{20}$ As Ann Haaker notes however, Brome had been assured by the Salisbury Court players that the annual stipulation of three plays was no more than a guarantee of dedication, and that given his loyalty and hard-work for the company, he need not produce more plays than he 'could or should be able well and conveniently to do and perform'. ${ }^{21}$ Heton's demands for the plays owed in arrears, and the testimony of the court documents, contradict this liberal interpretation. Brome had argued, furthermore, against the normalcy of halting weekly payments during plague time, unless specified between the company and dramatist. The interpretative gap between what the contract explicitly stated and what it failed to articulate struggles over definitions of standard theatrical practice, and reveals the fundamental discontinuity 
in the theatrical ideologies that Brome and Heton attempt to naturalize in competition.

The patterns of production identifiable in the work of contemporary playwrights are a further consideration in the assessment of the typicality of Brome's contractual binding. An analysis of professional attachments reveals that contractual obligation such as defined in the Brome-Heton documents is an inappropriate description of common methods of production, which doesn't always apply. John Fletcher's dramatic production does not resemble exclusive contractual behaviour until after Shakespeare's death, after which he may have taken on a share in the company that would effectively ensure his loyalty. While from 1610 the King's Men performed an average of one of his plays a year, from 1607 to 1615, Fletcher also produced at least seven plays performed by the Children of the Queen's Revels and Lady Elizabeth's Men. ${ }^{22}$ During the years 1597 to 1602, Ben Jonson was writing for the Lord Admiral's Men, the Lord Chamberlain's, and the Queen's Revels, followed by the composition of Bartholomew Fair for Lady Elizabeth's Men at the Hope. There follows a period of sustained but erratic work for the King's Men, culminating in $A$ Tale of A Tub for Queen Henrietta's.

Jonson's tendency to work periodically for a set of established employers while branching into new relationships and securing relatively short-term associations with a variety of companies is also evident in the professional strategies of both Dekker and Heywood. Dekker's career exhibits the most variance, in his commitment to nine theatrical companies. Gurr observes that some dramatists of the period 'shopped around with their services', ${ }^{23}$ but Dekker's activities are placed into perspective by the recognition that strong elements of continuity exist among many of these troupes, which constituted various components and stages of the Henslowe enterprize: the Admiral's Men, Worcester's, and the Prince's Men. Yet interspersed among these associations are three plays that were performed by the Children of St. Paul's. ${ }^{24}$ These dual commitments were succeeded by three plays for the Queen Anne's/Red Bull Revels company, followed by two for Prince Charles' Men, and one for Lady Elizabeth's (all of which played at the Cockpit between 1617-1625). Similar patterns of association are also present in Heywood's commitments. After a relatively long-term attachment to the Henslowe companies as a player and (secondarily) a playwright, following the 1597 bonds, Heywood turned his attention to the Beeston companies, followed by a brief but concentrated spell with the King's Men. Similarly, Ford transferred company allegiances frequently while maintaining a net- 
work of companies the employment of which he might return to. Most interestingly, Ford appears to have written for Queen Henrietta's Men and the King's Men intermittently, interspersing his ten-year association with the Cockpit with a six year interval productive of (at least) three Blackfriars plays.

These production patterns and rates reveal that dramatists, driven by opportunism and commercialism, appear to have established relationships and networks with a number of companies, which they could maintain simultaneously and might revisit. They reveal no evidence of contractual obligation as stringent as Brome's. The playwright to whom the tenets of Brome's contract is most frequently applied is James Shirley, in the interpretation of his steady production of plays for the Cockpit. Gurr describes Shirley as the Cockpit's 'resident writer' ${ }^{25}$, and Bentley states that 'he was associated with the company as no other playwright was' 26 . Bentley perceives a pattern of an average two plays a year for the company, suggestive to him of contractual conditions identical in essence, though less demanding, to those of Brome. While the vagaries of dating plays will always provide obstacles to interpretation, Shirley's activities are unusually clearly recorded in Herbert's office-book, and suggest that the annual quantity of plays produced by Shirley rose significantly from 1631 until 1635. The intervention of plague might explain these variations, which in turn implies-rather than a regulated yearly quota, as defined by Heton-the intervention of circumstantial factors such as supply and demand. ${ }^{27}$ These factors might also be affected by what other playwrights were doing at the time: it may not be coincidental that in the years prior to 1631, when Shirley was at his least active for Queen Henrietta's Men and producing an average of one play every eighteen months, Heywood and Brome were immersed in their most active engagement with the company.

In the midst of his activity for Queen Henrietta's Men, Shirley composed The Changes performed by the King's Revels at Salisbury Court-a case, frequently neglected by theatre historians, which has significant consequences for the interpretation of his association with the Cockpit. If Shirley had been formally contracted to the company, this play would dishonour such an agreement in a manner identical to Brome's apparent transgression. We hear of no legal action or discontent over Shirley's 'infidelity', however, and in the context of the patterns of production of his contemporaries, Shirley's deviance from a permanent commitment to only one company is far more representative of playwriting customs than the requirements of Heton. It is 
also the way in which Brome seems accustomed to working. Before 1635, Brome had worked for Prince Charles' Men at the Red Bull—an arrangement in which, as Brome states in the depositions, he was 'very well intertayned and truly paied without murmering or wranglinge'. ${ }^{28}$ The Prince's Men not only keep Brome's services on good terms, but also appear to have accepted his involvement in projects that were extraneous (and potentially opposed) to their own interests, for in 1634 Brome wrote The Late Lancashire Witches with Heywood for the King's Men. ${ }^{29}$

The condition of exclusive loyalty to a company rarely held, then. It is more helpful to consider the nature of the theatrical market, even as established as it was by the 1630s, as governed by the variable factors of plague time, repertory strategy, and playwright availability, than as a regulated and stable enterprise. The essential concern of the contract-holding manager remained not only the provision of new plays as assets for his company, but also the maintenance of an established core of repertory, composed of a significant proportion of revivals in the Caroline period. This meant that while the production of new plays was still a primary concern of managers, the commodity provided by the playwright and that provided by the player differed in value more than ever; a state of affairs reflected in the contractual binding of players. Dramatists were required to stock the playhouses with which they chose to associate themselves as and when new plays were needed - and this level of commitment was dependent not only on factors such as plague closure, but also upon the relations and commissions struck by the company with other dramatists. Furthermore, there were mutual benefits for playwrights and companies to work regularly together, beyond the ownership of shares and contractual bindings: the identification of a company that required a dramatists' services indefinitely or periodically was also a situation that might be manipulated through his provision of repertory and establishment of particular kinds of fare. As Joseph Loewenstein suggests, internal company relations 'maintained the loose linkages of company, performance style, distinctive performers and dramaturgic idiom that gave the theatrical 'market' its coherence'. ${ }^{30}$ The influence that playwrights had over the creation of expectations in company repertory and fare, perpetuating and shaping traditions and market niches for commercial exploitation, constituted an essential part of this market. Other advantages of committing to a company were more practical—a working knowledge of a specific playhouse's performance conditions, for example, or familiarity with readily available property and costume holdings. Shirley's association 
with Beeston's Cockpit, and Fletcher and Massinger's with the King's Men, may have been prompted by no more than such considerations: we need not infer the contract from what looks at first to be 'contractual' behaviour.

The extent to which Brome's contract was unusually strict, and to which he understood it as negotiable, also indicates the reformulation of managerial priorities into the 1630s - or at least those of Heton. Beeston and Gunnell had both emerged from backgrounds of playing and (presumably) had some appreciation of the conditions entailed by the everyday operation of theatrical companies. Henslowe had gradually developed these familiar expectations and procedures over his life-long career; yet Heton's position as a manager is unique, as he possessed no expertise in theatrical enterprises. The unforgiving conditions of his contract, misunderstandings generated in its discursive formalisation, contradictory conceptions of playhouse practice, energetic demands for legal compensation, and repeated misplacement of emphasis upon Brome's word (his orally delivered promise) may demonstrate professional inexperience and naivety rather than shrewd autocracy. Matthew Steggle has drawn attention to the immediate historical context of the contract's breaking, which involved the movement of two playersGeorge Stutville and Edward Gibbs-from Salisbury Court to join the new Cockpit company of Beeston's Boys — which may have been assisted by intervention on the part of Sir Henry Herbert, Master of the Revels. Steggle observes that 'Brome was not the only theatre worker whose loyalties at this time were being transferred from the King's Revels to Beeston', prompting Heton's concern and subsequent court action. ${ }^{31}$ Martin Butler has recently taken up this argument in an analysis of impresarial models of management, and also argues that Heton's 'distinctive' managerialism was 'reactive' rather than preordained: 'an attitude that crystallised haphazardly in response to changing circumstances', which included not only Brome's infidelity, but ongoing antagonism with the Cockpit playhouse. ${ }^{32}$

Heton was moving, at the same time, to formalize relations and tighten his governance through written conditions across the entire company: maintaining contractual relations with Brome was just part of this process. $\mathrm{He}$ argued in the collection of documents now held in the British Library and known as 'Heton's Papers', that written conditions 'would be the occasion to avoyd many differences and disturbances that happen both betwene the Company and housekeepers, amongst the Company themselves, and many generall discontents'. One of these discontents appears to be the unreliability of his players: Heton complains that 'for their owne benefite compan- 
ies of Actors have removed from their residence, and dispersed themselves into severall places, soe that noe certaine place of abode is knowne where they may be found'. ${ }^{33}$ Steggle has pointed out that the circumstances surrounding Brome's contract suggest that 'stage-writers were regarded as only one element of the theatrical machine, rather than being in a unique class by themselves'. ${ }^{34}$ These are certainly the terms in which Heton regarded Brome, as a supplier of plays that required regulating in terms comparable to the players of the company. But as the evidence suggests, dramatists appear to have exerted a degree of autonomy over the professional relations that they struck: this model was not paradigmatic. The necessity that Heton felt for formal contracts and the inadequacy of the spoken promise-for Heton and, as it emerged, for Brome in a court of law following his liberal interpretation of the required quantity of plays - highlights the vulnerability of the 'impresarial' manager in this specific instance: Gunnell and Heton needed Brome's plays, and Brome was quick to recognise this in his observation that the Salisbury Court company was in the Infancie of theire setting upp'. ${ }^{35}$

The extent of Brome's own dependency upon Heton and the conditions of the contract has also recently been confirmed. Owing to new documents discovered by Eleanor Lowe in the course of research undertaken for the Complete Works of Richard Brome project, it is possible to consider specific motivations that may have prompted Brome to subscribe to Heton's demands, despite their stringency. Lowe has identified Brome's signature in a series of rent books belonging to the archives of the Charterhouse Hospital, which record payments made to pensioners resident at the Charterhouse. ${ }^{36}$ This affirmation of Brome's poverty at the end of his life adds further nuance to his professional activities prior to this. Heton's contract pre-empted any opportunity for Brome to raise extra funds from the publication of his plays: it categorizes even the textual afterlife of his drama as company property, explicitly specifying that Brome 'should not suffer any playe made or to bee made or Composed by him for $\mathrm{yo}^{\mathrm{r}}$ subiects or theire successors in the said Companye in Salsbury Courte to bee printed ... without the License from the said Companye. ${ }^{37}$ On the other hand, contracted work meant that he was paid regularly, regardless of the amount of plays that he actually produced: in theory, he had a fixed weekly salary, rather than living from the unpredictable profits made from his drama and returns from any shares that he may have held. These special and specific conditions that held, both for Brome and Heton, serve to contextualise the 
contract and its attempted enforcement, in ways that undermine is application as paradigmatic.

The resituation of Brome's contract that is offered here reveals the fundamentally vexed and particular conditions of its nature. The breaking of Brome's contract, rather than our knowledge of its existence, constitutes the 'primary significance' of these documents, and reveals far more of the characteristic relations between dramatist and company than the conditions of the contract are able to reveal. This paper reveals the importance of contextualization as a critical approach, and the extent to which our narratives of early modern theatre history - particularly those of the 1630s—are grounded upon generalizations that require careful reworking and examination, with implications for the status and autonomy of the renaissance dramatist, the role of the impresarial manager, and the ways in which repertories were acquired in the established and competitive environment of the Caroline theatre.

ELEANOR COLLINS

\section{Notes}

1 See, for instance, G. E. Bentley. The Jacobean and Caroline Stage, 7 vols. (Oxford, 1956) 5: 1068: 'the regularity of his composition for plays for the Cockpit suggests that he may have had a contract with Christopher Beeston similar to that of Richard Brome'.

2 Andrew Gurr, The Shakespearian Playing Companies (Oxford, 1996) 9.

3 Ibid., 8.

4 Ibid, 16.

5 Bentley, The Jacobean and Caroline Stage, 3: 53

6 For a full transcript of the depositions and a discussion, see Ann Haaker, 'The Plague, The Theatre, and the Poet', Renaissance Drama n.s.1 (1968): 283-306, esp. 297.

7 Ibid, 298.

8 Ibid, 299-300.

9 At various points, G. E. Bentley has speculated about contractual relations for Fletcher, Massinger, and Shirley. Bentley. Bentley states of the King's Men that 'It seems likely that they entered into some sort of contract with Fletcher' (3: 308). Of Massinger, Bentley indicates that his plays written for the Cockpit 'show that Massinger was evidently not bound by contract to the King's company in the last 
years of Fletcher's life ... [I]t is possible that a better dating of the plays might show a complete break with the King's company and an attachment to Beeston's troupes for two or three years ... [A]fter Fletcher's death in August 1625 Massinger became the regular dramatist for the King's Men' (4: 754-5). Bentley also writes that 'Evidently Shirley was under contract to the company or the manager of the Phoenix, as Richard Brome is known to be at Salisbury Court' (1:227).

10 Mark R. Benbow, 'Dutton and Goffe versus Broughton: a disputed contract for plays in the 1570', REED Newsletter (1981) 3-9.

11 R.A. Foakes (ed.), Henslowe's Diary, 2 ${ }^{\text {nd }}$ ed. (Cambridge, 2002), 105.

12 Ibid, 199.

13 Ibid, 238-41.

14 E. K. Chambers, The Elizabethan Stage, 4 vols. (Oxford, 1923) 2: 131.

15 Bentley, The Jacobean and Caroline Stage, 6: 158.

16 K. E. McLuskie, and Rebecca Rogers, 'Who Invested in Early Modern Theatre?'. Research Opportunities in Medieval and Renaissance Drama 41 (2002), 38.

17 Roslyn Knutson, Playing Companies and Commerce in Shakespeare's Time (Cambridge, 2001), 55.

18 Jonson's Every Man in His Humour and Every Man Out of His Humour were performed by the Chamberlain's Men in 1598 and 1599; from c. 1597 to 1609 Jonson wrote for the Children of the Queen's Revels at the Blackfriars, contributing five plays between 1600 and 1609 (The Case is Altered, Cynthia's Revels, The Poetaster, Eastward Ho! (with Chapman and Marston) and Epicoene). From 1603 he was concurrently writing for the King's (previously Chamberlain's Men), before selling Bartholomew Fair to Lady Elizabeth's Men, who were playing at this time at Henslowe's Hope Theatre.

19 Knutson, Playing Companies and Commerce, 55.

20 Haaker, 'The Plague, The Theatre, and the Poet', 301.

21 Ibid, 302

22 In 1613, the Children of the Queen's Revels merged with the Lady Elizabeth's Men, who appear to have inherited some of their plays. Fletcher wrote The Knight of the Burning Pestle and The Scornful Lady for the Children of the Revels with Francis Beaumont, and (alone) Cupid's Revenge. After 1613, it appears that he wrote The Honest Man's Fortune and, with Beaumont, Wit Without Money, for Lady Elizabeth's Men. Monsieur Thomas and The Nightwalker were written for either the Queen's Revels company or Lady Elizabeth's.

23 Andrew Gurr, The Shakespearean Stage, 1576-1642 $3^{\text {rd }}$ ed. (Cambridge, 1995) 20. 
24 These were Satiromastix, performed jointly by the Children of St. Paul's and the Lord Chamberlain's Men and published in 1602, and Westward Ho! and Northward Ho! (1604-5).

25 Gurr, Playing Companies, 419.

26 Bentley, The Jacobean and Caroline Stage, 1: 227

27 As Leeds Barroll examines in Politics, Plague and Shakespeare's Theater: The Stuart Years (Ithaca, 1991), and Haaker emphasises in 'The Plague, The Theatre, and the Poet', 287-9.

28 Haaker, 'The Plague, The Theatre, and the Poet', 301

29 Interestingly, Heywood was distracted by this play from his work for the Cockpit in the same way that Brome was from the Red Bull; their collaboration on The Late Lancashire Witches constitutes a break from their usual working pattern at this time that again highlights the peculiarity of its provenance - see Herbert Berry, 'The Globe Bewitched and El Hombre Fiel', Medieval and Renaissance Drama in England 1 (1984): 211-230; Heather Hirschfeld, 'Collaborating Across Generations: Thomas Heywood, Richard Brome, and the Production of The Late Lancashire Witches, and lately Kathleen E. McLuskie, 'Politics and Aesthetic Pleasure in 1630s Theater' in Adam Zucker and Alan B. Farmer (eds), Localizing Caroline Drama: Politics and Economics of the Early Modern Stage (New York, 2006), 43-68. At the same time, it illuminates the entrepreneurship of professional dramatists, and the fact that they were at liberty to make the most of opportunities as they arose.

30 Joseph Loewenstein, Ben Jonson and Possessive Authorship (Cambridge, 2002) $55 .$.

31 Matthew Steggle, Richard Brome, Place and Politics on the Caroline Stage (Manchester, 2004) 107.

32 Martin Butler, 'Exeunt Fighting: Poets, Players, and Impresarios at The Caroline Hall Theaters', in Zucker and Farmer, Localizing Caroline Drama, 97-128.

33 For Richard Heton's Papers, see Bentley, The Jacobean and Caroline Stage, 2: 684-7 and Peter Cunningham, Shakespeare Societ'sy Papers, 4 vols. (London, 1844-9), 4: $95-100$.

34 Steggle, Richard Brome, 107.

35 Haaker, 'The Plague, The Theatre, and the Poet', 301.

36 Eleanor Lowe, 'Confirmation of Richard Brome's Final Years in Charterhouse Hospital', Notes \& Queries, 54:4 (December 2007).

37 Haaker, 'The Plague, The Theatre, and the Poet', 298. 